\title{
Southbank Skateboarding, London and Urban Culture: the Undercroft, Hungerford Bridge and House of Vans
}

Iain Borden

Chapter in Kara-Jane Lombard (ed.), Skateboarding: Subcultures, Sites and Shifts (Abingdon: Routledge, 2015/forthcoming).

Over the last few years, skateboarding spaces in London have been subject to considerable controversy and development. Issues raised include democracy, public space, cultural value, historic preservation, commerce and urban design. There has been correspondingly widespread media attention, while the opinions of those involved have been fiercely expressed. This chapter takes an overview of three different but closely adjacent skateboarding spaces, and explores their connection with wider urban culture: the "Undercroft"' at the Southbank Centre (SBC), and how a skate space can intensify debates over architectural, historical, usage and legal aspects of public space; the proposed 'Hungerford Bridge'" skate space, also at the SBC, and how skate spaces might be designed differently to conventional skateparks and skateplazas; and the nearby "House of Vans", and how skateboarding is integrated within wider design, artistic and commercial operations.

\section{The Undercroft}

When the Hayward Gallery, Queen Elizabeth Hall and Purcell Room (Festival Wing) complex at the SBC in 1967, three of its architects belonged to the radical architectural group Archigram. According to their architectural ideas, the Festival Wing's meandering walkways and ground-level spaces - the latter commonly referred to today as the "Undercroft" - were left open for unpredictable and unknown uses. (SBC 2013a) Consequently, when skateboarding first came along in 1973, (LLSB 2014a) it provided exactly the unexpected eruption of creativity for which these architects had hoped. Where the designers had produced flat spaces surrounded by apparently uselessly-angled banks, the skateboarders saw these same slopes as providing a freely accessible version of the commercial skateparks then being constructed across the world, including London's 'Skate City' along the River Thames. The Undercroft roof was another bonus, under which - up and down tangled banks and between curious Doric-mushroom columns - up to a thousand skateboarders at a time freely emulated the surf-style skateboarding being promoted in magazines like Skateboard! and Skateboarder. (Borden 2001) 
As this suggests, architecture here is far more than a building as concrete structure, and is also comprised of what people do there. As philosopher Henri Lefebvre (1991) has argued, architectural and urban space is made up of the physical places we use (the Festival Wing's Brutalist concrete spaces), the conscious ideas we have (the architects' designs), and also people's actual, everyday experiences (skateboarders and other users).

Skateboarding, therefore, is absolutely part of the SBC, not as a history of architecture as a physical monument, design invention or national symbol, but as a place where people - skateboarders and others - have made an extraordinary expression of youthful energy and joy. Nor has skateboarding been a short-lived moment in the history of the SBC; having been in the Undercroft for nigh on forty years, this is very probably the oldest place in the world which has been subjected to skateboarding in a continuous and intensive manner.

\section{IMAGE 1 NEAR HERE}

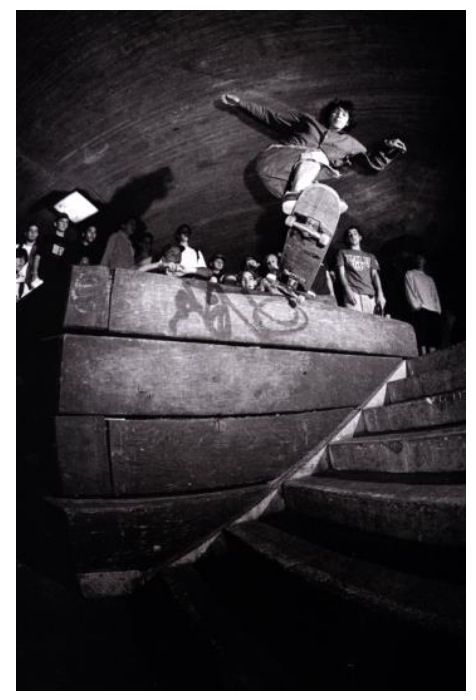

Skateboarders' determined usage of the Undercroft was particularly evident during the 1980s and 1990s. In these years, after many skateparks had closed by the early 1980s, a new streetbased skateboarding emerged, with skateboarders using the "ollie"' move to ride over the ledges, handrails and other paraphernalia of everyday spaces. The Undercroft changed too, becoming less like a free skatepark and more like a city street, somewhere appropriated both by skateboarders and the homeless, whose 2,000 or more shelters constituted Southbank's 'Cardboard City''; according to The spectator, amid this otherwise "godforsaken waste-land'" the skateboarders provided 'one of the few rational purposes'' and "some small evidence of human life."' (Wheatcroft 1979)

The Undercroft changed again in 2004 and in 2006, when several skateable concrete and stone blocks were installed by Richard "Badger"' Holland and skateboard-arts group The Side Effects of 
Urethane, with financial support from Sony Playstation, Nike, Casio G-shock and Olympus. (Holland 2015) This initiative rendered the space particularly suited to street skateboarding. "At a time when a good ledge spot was the holy grail,"' enthused Jake Sawyer, "this really was a godsend.'' (LLSB 2014b) At the same time, the SBC organised other niceties, such as lighting, CCTV and a benign police presence to reduce petty crime. Railings and yellow lines demarcated a skateboardable space for the SBC's liability insurance, and so legally allowed skateboarding to occur.

\section{IMAGE 2 NEAR HERE}

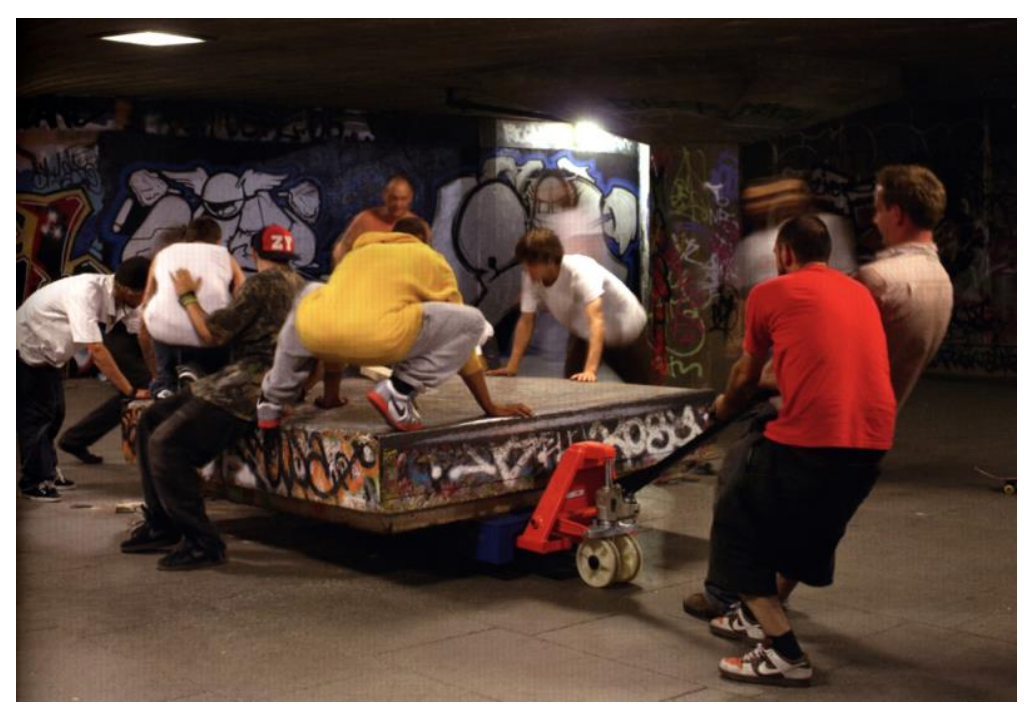

Murals and graffiti also started to appear in the Undercroft (again with SBC permission), marking it as a centre for varied urban arts. BMX-riders, photographers, film-makers, poets, dancers and musicians were now being increasingly drawn to the spot. As photographer Wig Worland noted, the "complete no-mans land"' Undercroft facilitated a "studio in the street"' where "no one would bother you,"' while skater Nick Jensen has similarly commented on how "the attitude at Southbank has informed the style and aesthetics' of his art work. For Karim Bakthouai, the social space mattered most, the Undercroft allowing an escape from gangland crime and other council estate constraints: "All the people I know like, they all fucking in jail, I didn't want that, I ain't about that, I'd rather be skating."' (LLSB 2014b)

Despite these positive attributes and the SBC's own improvements to the Undercroft, and while recognising it was, according to Mike McCart (then SBC Commercial Director), "the Mecca of skating in the world', over 2004-05 the SBC still reduced by two-thirds the amount of skate space available. This assertive action recalled past episodes when skateboarding had been discouraged, such as the mid1980s when SBC security teams scattered stones, prized up paving slabs and generally made skaters' lives uncomfortable. Alternative 
SBC tactics in other years have included turning off evening lighting, hosing down the floors, drilling grooves and adding rails to some of the banks. (LLSB 2014a, 2014b)

Despite all this history, skateboarding at the Undercroft has continued to prosper, the Undercroft achieving near mythic status as the epicentre of UK skateboarding, where tens of thousands have learned their craft, from novices to professionals, and from hardcore locals to occasional visitors. The Undercroft lays strong claim to being UK skateboarding's most precious home, its original Garden of Eden, oldest sparring partner and most famous Wembley arena - all rolled into one. It is also a place of pilgrimage for skateboarders worldwide, coming long distances to roll across one of skateboarding's most hallowed grounds.

Given all this, it is unsurprising that large numbers of skaters and general public alike reacted extremely unfavourably to the SBC's suggestion in March 2013 that, to help fund a massive £100+ million package of improvements to the Festival Wing, the Undercroft should be turned into retail units, with skaters being relocated to the adjacent Hungerford Bridge site. (SBC 2013c) United mostly under the "Long Live Southbank" (LLSB) banner, carefully orchestrated by Paul Richards and others, and possibly also enjoying oft-rumoured substantial financial backing from the father of Undercroft skater Tom "Blondey"' McCoy (Butter 2014), these objectors mounted a skilful oppositional campaign under the headings of 'You Can't Move History", "Preservation and Not Relocation"' and "Construction Without Destruction.' Significantly, in contrast to the SBC's press releases and marketing statements, LLSB eschewed any formal PR representation in favour of a highly effective amalgam of the physical (on-site presence, marches and events) and the digital (online petitions, website, YouTube, Twitter, Facebook etc.) - a strategy which later won 'engagement campaign of the year' at the annual Change Opinion Awards.

Widespread backing came from the skateboard community, musicians, artists, general public and British MPs Kate Hoey and Ben Bradshaw. Most importantly, after 150,000 people had signed a petition supporting LLSB and over 27,000 had opposed the SBC planning application, the Conservative party Mayor of London, Boris Johnson, seized the political opportunity to back the LLSB, calling the Undercroft "the epicentre of UK skateboarding" and "part of the cultural fabric of London." As Johnson saw it, this "much-loved community space" also "attracts tourists from across the world and undoubtedly adds to the vibrancy of the area."' Effectively vetoing the SBC's planning application, Johnson's declaration was a decisive moment in LLSB's eventual victory. (LLSB 2014a; Brown 2014; SBC 2014a) 
Moreover, legal factors were at play. Simon Ricketts, partner of King \& Wood Mallesons SJ Berwin, and the UK's most highly rated planning lawyer, worked with LLSB to have the Undercroft designated an "Asset of Community Value"' (ACV) under the Localism Act 2011, and also sought to have it designated as a "Town or Village Green'" under the Commons Act 2006. (LLSB 2014a, 2014b; Butter 2014) While the ACV was a political success for LLSB, it actually did little to secure skateboarding's future at the site. However, the possibility of the Undercroft being classified a town or village green was much more threatening to the SBC, both in case any decision went against them and because of mounting legal costs. Faced with this public, political and legal turmoil, the SBC leadership - artistic director Jude Kelly, chief executive Alan Bishop and governing board chairman Rick Haythornthwaite - finally capitulated in January 2014, signing a section 106 planning agreement with Lambeth borough council, and so effectively securing the Undercroft for skateboarding in perpetuity. (Brown 2014)

Stepping away from this LLSB victory, however significant it may be for skateboarding, it is worth remembering why so many nonskateboarders have also come to the Undercroft and supported the LLSB. People from all over London and wider world enjoy seeing the Undercroft's unique combination of skateboarding-against-concrete, of unruly disorder amidst increasing sanitization, and so witnessing a truly public space in action. Skateboarding at the Undercroft is "inspiring and uplifting,"' commented one member of the public. "It promotes all kind of values that we need in this society."' Or as another noted, "take away the diversity of the southbank and you will kill the charm."' (LLSB 2014a) Even the conservatively-minded The Times proclaimed that destroying the skate space to provide retail outlets would amount to "cultural vandalism." (Purves 2013)

This is important stuff, and transcends the immediate needs of skateboarding to speak to a larger question as to the kinds of public spaces we desire today. As David Harvey has noted, the "right to the city [...] is not merely a right of access to what the property speculators and state planners define, but an active right to make the city different, to shape it more in accord with our heart's desire, and to re-make ourselves thereby in a different image." (Harvey 2003) In concert with Harvey, skateboarding at the Undercroft suggests that public spaces can be richer than typical shopping malls or high streets, where coffee outlets, branded shops and chain restaurants abound. It suggests that different people doing different things perceive and enjoy city spaces in different ways. It suggests that we would like our cities to be similarly varied, at once loud and quiet, rough and smooth, colourful and monochrome, flat and angled. And, above all, it suggests that we most enjoy cities and buildings when they both comfort and challenge us, when they provide 
us with things which we both expect and cannot anticipate.

Skateboarding at the Undercroft and SBC is, then, one small yet vital part of this process.

\section{Hungerford Bridge}

When the SBC proposed moving skateboarding $125 \mathrm{~m}$ from the Undercroft to a comparably sized 1,200m2 and visible site beneath the railway Hungerford Bridge - for many this very suggestion disclosed a lack of understanding as to what street-based skateboarding was about. Equally serious design challenges were also therefore implicated. How could this new Hungerford Bridge space avoid institutionalizing street-based skateboarding within a skatepark-like environment? What might it look like, feel like and operate? Who could design it? And how might it relate to the Undercroft?

To pursue these questions, during 2013 Richard Holland, Søren Nordal Enevoldsen of SNE Architects and myself worked with the SBC to develop the new facility's brief and design. (Borden and Holland, 2013a) In doing so, we continued to argue vehemently that skateboarding should remain at the Undercroft, and we supported the LLSB via publications, videos and other contributions. (Borden 2013, 2014a; LLSB 2013a) I had also contributed to previous campaigns supporting the Undercroft, including the "Save Southbank"' documentary (Whitter and Shuall, 2008). But we also felt that Hungerford Bridge might offer some benefits as a temporary or permanent Undercroft replacement, or possibly as an additional facility. Given that the SBC were committing over $£ 1$ million to the new space and guaranteeing its skateboarding use for 125 years (SBC 2013d) - quite possibly the most generous gesture ever made by a public institution towards skateboarding - this was surely worth investigating .

The initial brief drawn up by Holland and myself distilled the requirements of Undercroft skaters articulated at consultation meetings in April and May of 2013, such as views that the space 'doesn't get built as a standard concrete skate park"' and instead should "preserve the character of South Bank" and "create a lively and dynamic area that everyone can enjoy."' (SBC 2013b) The collaborative nature of the subsequent design development was deliberate and essential. As a long-time historian of skateboarding and urban space, I provided academic and theoretical input, as well as personal expertise as a skater since 1977. Holland, meanwhile, was producer of the Undercroft's street-style blocks - the prominently used of its features. He was also renowned as a skateboarder for 25 years, creator of numerous skateboard-able installations in Bermondsey, Helsinki, Lille, Peckham and Shoreditch (Borden and Holland, 2013b), and former co-owner of the local skate shop Cide, 
which had played a "pivotal role"' in supporting Southbank skateboarding. (LLSB, 2014b)

As architect for Hungerford Bridge (selected after an invited competition in mid 2013), Enevoldsen was perhaps uniquely qualified to take on the design role, having been previously responsible for Copenhagen's acclaimed 4,600 m2 Faelledparken skatepark. At another Copenhagen project, this time at Prags Boulevard, he had overseen an installation of furniture and equipment for skateboarding and parkour, while at the mixed-use Rabalder Parken in Roskilde a rainwater system is inventively re-purposed by Enevoldsen for skateboarding and other activities, recalling the drainage ditches appropriated by American skaters in the 1960s and 1970s. In addition, Enevoldsen was a committed street-skater, yielding further skateboarding experience. (Borden and Holland, 2013b). A Focus Design Group provided additional expert input, including Ricky Adam for BMX, Niall Neeson for skate culture, Tom Oswald for street art and James Sutton for parkour, as well as a professional street skateboarder (a regular Undercroft user who preferred to remain anonymous). Additional support was provided by the SBC's Mike McCart (Director of Policy \& Partnerships) and Mark Rushworth (Property Director), was well by a multi-disciplinary technical team. Finally, several design workshops with skaters and other users were held during octoberNovember 2013 to further enrich the designs. (Borden and Holland, 2013b; SBC 2013e)

Given the brief's origins in the desires of Undercroft skaters, the Hungerford Bridge designs unsurprisingly display many characteristics of typical street skateboarding spots such as Bercy (Paris), KulturForum (Berlin), MACBA (Barcelona) and the Undercroft: large and open flat-floor space surrounded by banks, ramps, ledges, steps and other features. Significantly, one of Enevoldsen's design tenets, underlining the scheme's difference with skateparks and skateplazas, was that everything had to have a multiple function, and nothing was solely for skateboarding. Furthermore, and again unlike smooth skatepark finishes, the materials proposed are typical urban flagstones, stone and brick, thus replicating the gritty textures of the Undercroft and other street spots. Besides a large brick wall for street art, several other extensive (and costly) site modifications included cutting away the underside of an existing concrete ramp to improve public visibility (about 9 million footfall pa), and an illuminated roof to provide rain protection from the porous railway overhead. (Borden and Holland, 2013b; SBC 2013e) 
IMAGE 3 NEAR HERE

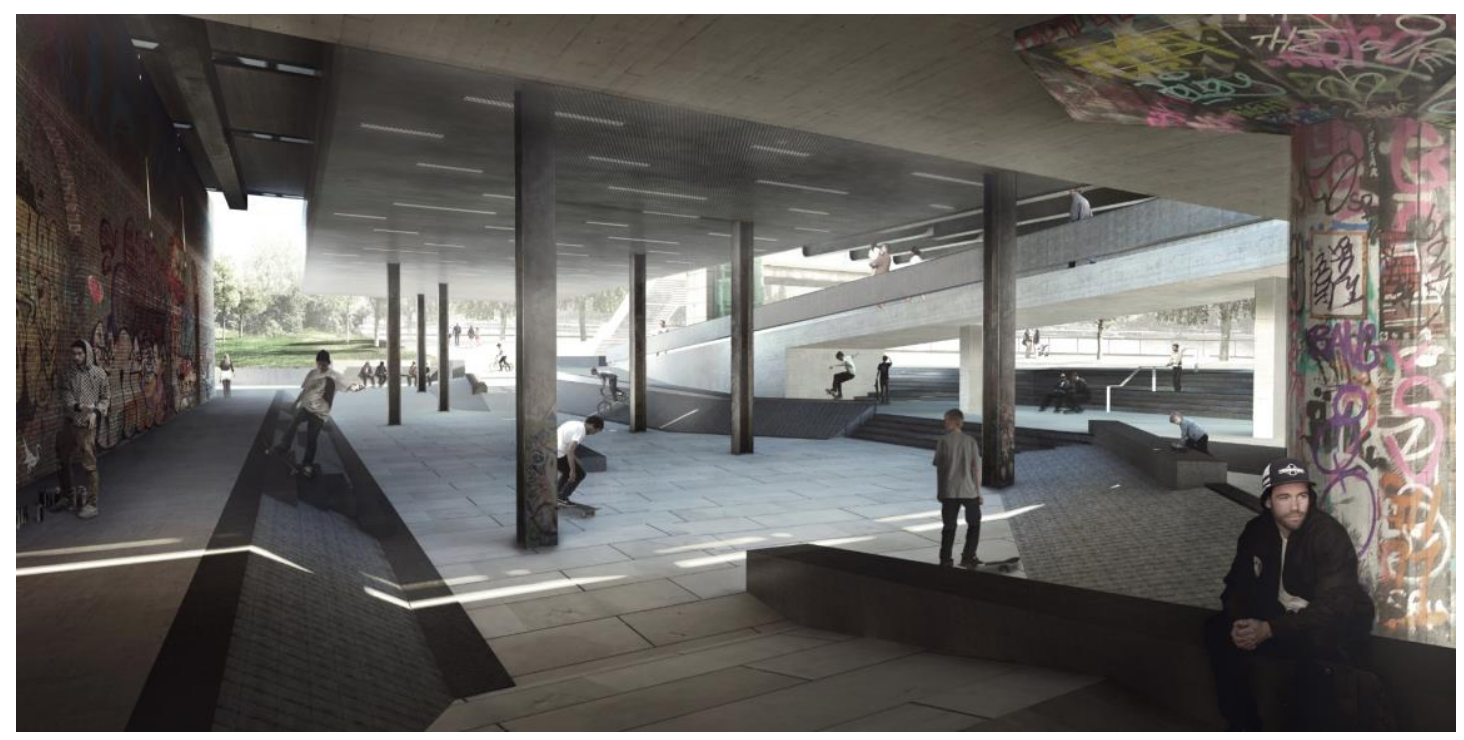

\section{IMAGE 4 NEAR HERE}

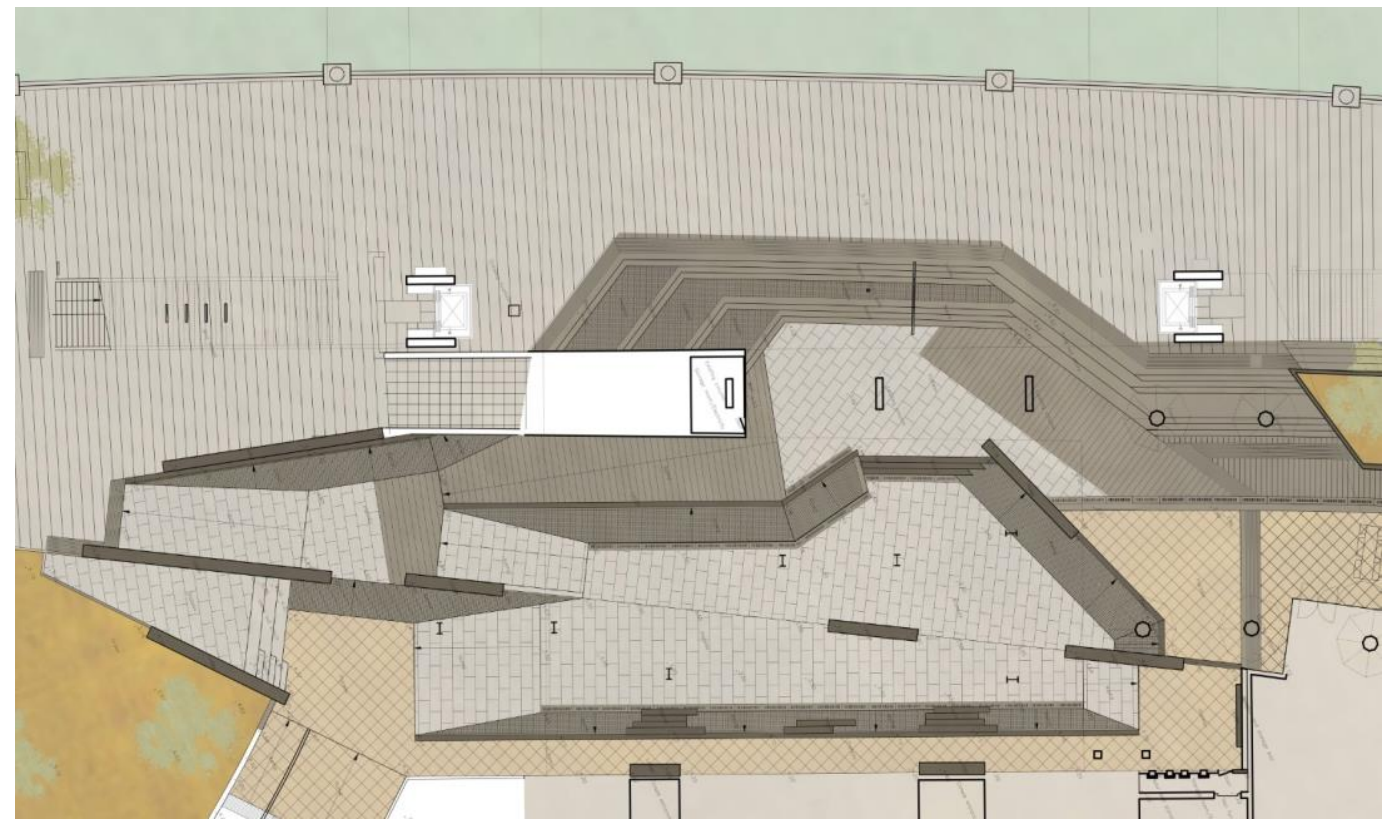

Overall, as Enevoldsen's design meant nothing was intended purely for skateboarding, the Hungerford Bridge design assumed the character of a public space that just happened to be good for skateboarding. While some skaters perceived it as being like the Whites Grounds skateplaza at London Bridge - a smaller, fenced and timetabled facility, operated under a local council's playground regime - and thus as a controlled place "oppressing the free expressive nature of skateboarding,"' (LLSB 2013b) others nonetheless disagreed with these comparisons. According to local skater Bedir Bekar, Hungerford Bridge provided "a true street-skateboarding spot"' which 'builds on the Undercroft's street heritage whilst providing the right flow and openness."' Others agreed. "What's 
being built is not a skatepark," stated Warwick Cairns. "It's a space: it has typical 'found space' features that can become a skate place in the minds, and through the actions, of skateboarders."' (Borden and Holland, 2013b)

Tellingly, yet other skaters remained unconvinced, frequently rejecting Hungerford Bridge on the a priori grounds that, as street skaters often prefer appropriating existing architecture rather than using purpose-designed skateparks, it is impossible to deliberately design architecture which is directed at skateboarders yet still attractive to them. "A found space such as this can never be recreated,"' remarks skater and photographer Jenna Selby of the Undercroft. "Those who try are blind to the very essence of what skating is about.'" (LLSB, 2014b)

Recent history, however, discloses numerous places worldwide where skateboard-friendly design has been successfully implemented into urban spaces and buildings, including the stealth-skateboardable Auditoria Park (Barcelona, Foreign Office Architects) and the Phaeno Science Centre (Wolfsburg, Zaha Hadid Architects). At the US\$700 million Opera House, (Oslo, 2008), architects snøhetta even consulted skateboarders regarding textures, materials and skateable areas. Parts of the building and surroundings are consequently arranged with marble ledges, kerbs, bench-like blocks and railings. (Blum 2008; Borden 2014b) Similarly, at the Landhausplatz ("LHP'") public plaza (Innsbruck, 2011), designed by LAAC Architekten and Stiefel Kramer Architecture, an undulating concrete surface of flats, banks, ledges, plateaus and blocks accommodates "a new mélange of urban activities"' suitable for pedestrians, skateboarders and BMX-riders alike. (Ritter, Treichl and Wedekind 2012; Dezeen 2011). Consequently, German skateboarding website Playboard.de (2014) describes LHP as providing "obstacles of all kinds which are perfectly integrated into the cityscape."'

Another example lies closer to the Undercroft. At the "Buszy"' (Milton Keynes, 2005), designed by architect Richard Ferrington and skateboarder Rob selley along with initial advice from myself, a floOK facility beside the train station offers a simple ledge and block arrangement under an open-sided roof. Buszy has been acclaimed by professional skateboarders as "the best spot they have ever skated' and by a UK skateboarding guide as 'easily one of the best block spots in the country''. (Armes 2008; Skates and Ladders 2009) Even the Undercroft itself suggests how Hungerford Bridge might attract street skaters, not least because its architects' preference for indeterminate uses may not have expressly included skateboarding but certainly allowed for its possibility. Even more tellingly, the Undercroft features used most extensively today - the skateable blocks installed by Holland et al - were indeed provided expressly 
for skateboarding, thus turning the space into something approaching a skateplaza or skatepark street course.

Even though the Hungerford Bridge site - nicknamed "Mellow Banks"' and "Bird Shit Banks"' by local skaters, (LLSB 2014a) - had previously accommodated skateboarding, another challenge has undoubtedly been its potential to counter the LLSB claim that "you can't move history', and which I myself asserted in an early LLSB video. (Borden 2013) Certainly Hungerford Bridge cannot compete with the Undercroft's decades-long association with skateboarding. Here, skateboarding has created a personal, collective, mental and sensual relationship with Brutalist architecture, a history composed from memories and events, pleasure and pain, belonging and alienation, trial and tribulation. Notable Undercroft events have included innumerable skate jams, demos, visits and videos made by professional teams, and even appearing in video games like Thrasher: Skate and Destroy and Tony Hawk's Pro Skater. As such, many Undercroft histories are composite and international, as revealed by professional skater description of the space being 'as well known to skateboarders around the world as Big Ben or Buckingham Palace."' (LLSB 2014a). Even more telling are myriad personal histories, the product of the thousands and generations of local skaters. Typical here is Southbank Sam's impassioned description of the Undercroft as a place which 'means everything to me. It's my life, when this place closes my heart will break.'' (LLSB 2014a, $2014 \mathrm{~b}$ )

Even here, however, there are counter-arguments. While a cultural practice's previous history cannot be moved or replicated ontologically it always remains in the past - the on-going and future history can change, such that similarly embodied practices from markets to football stadia (like Borough Market, Wembley and Arsenal's Emirates stadium in London) have all flourished after geographic transplantation and architectural transformation. Furthermore, the idea that history is intransigent runs contrary to street skateboarding's mobile and transitory nature, exploiting a particular spot for months, days or minutes, and then moving quickly on. As skater Aaron Bleasdale once commented, London skaters prefer not to stay in one place but 'go and skate the streets - there's sick spots everywhere.'" (Bleasdale 1996) Indeed, the history of street skateboarding is in many ways a constant search for new skateable terrains and opportunities. (Borden, 2001)

Nonetheless, despite this tendency towards perpetual mobility, certain places do become skateboarded for months, years or even decades. Even these skate spots, however, can move successfully move location. At Montreal's "Big O'" - originally constructed as an entrance tunnel for 1976 Olympics athletes - this raw concrete structure had been appropriated by skateboarders and covered in 
graffiti - just like the Undercroft. Faced with impending demolition in 2011, due to construction of the Montreal Impact soccer stadium, the skateboarders worked with the authorities to physically move the tunnel $50 \mathrm{~m}$. Re-opened in 2013, Big O's relocation has been celebrated as a victory for skateboarders and Montreal Impact alike, confirming skateboarding's on-going presence in the city. (Tison and Walsh 2006; Ethernal Skate Films 2013)

Another variation of this theme is evident at Paine's Park. Following the controversial banning of skateboarding from the "Love Park', square in downtown Philadelphia, (Howell 2005) this US\$4.5 million facility for street-based skateboarding was opened in 2013 in a nearby waterside park, next to Philadelphia Museum of Art. Designed by architect Anthony Bracali with local skateboarders, and financed by the Franklin's Paine Skatepark Fund, it offers 2.5 acres with brick banks, handrails, stone ledges, stairs and blocks, and even benches rescued from Love Park. As Bracali explains, as with Hungerford Bridge, the main idea was for a skateboardable space that looked unlike a skatepark, "a great public space that just happened to be a skate park,"' thus merging different uses and so allowing the space to be "more usable and sustainable over time." (Clark and Hyland 2013)

Although some skaters do view the facility as being too much like a skatepark, and not enough like a real public space, Paine's Park has nonetheless been generally welcomed by skateboard blogs such as Quartersnacks (Quartersnacks 2013) and praised for attracting skateboarders, BMX-riders and general public alike. (Owens 2014) Significantly, locals have also appreciated the varied skaters attracted to the site: "I am a little heavier, and I still don't know how to kick flip,"' noted Michael Haeflinger. "But at Paine's, [e]veryone is so mellow and supportive and friendly."' (Philly Love Notes 2013) 


\section{IMAGE 5 NEAR HERE}

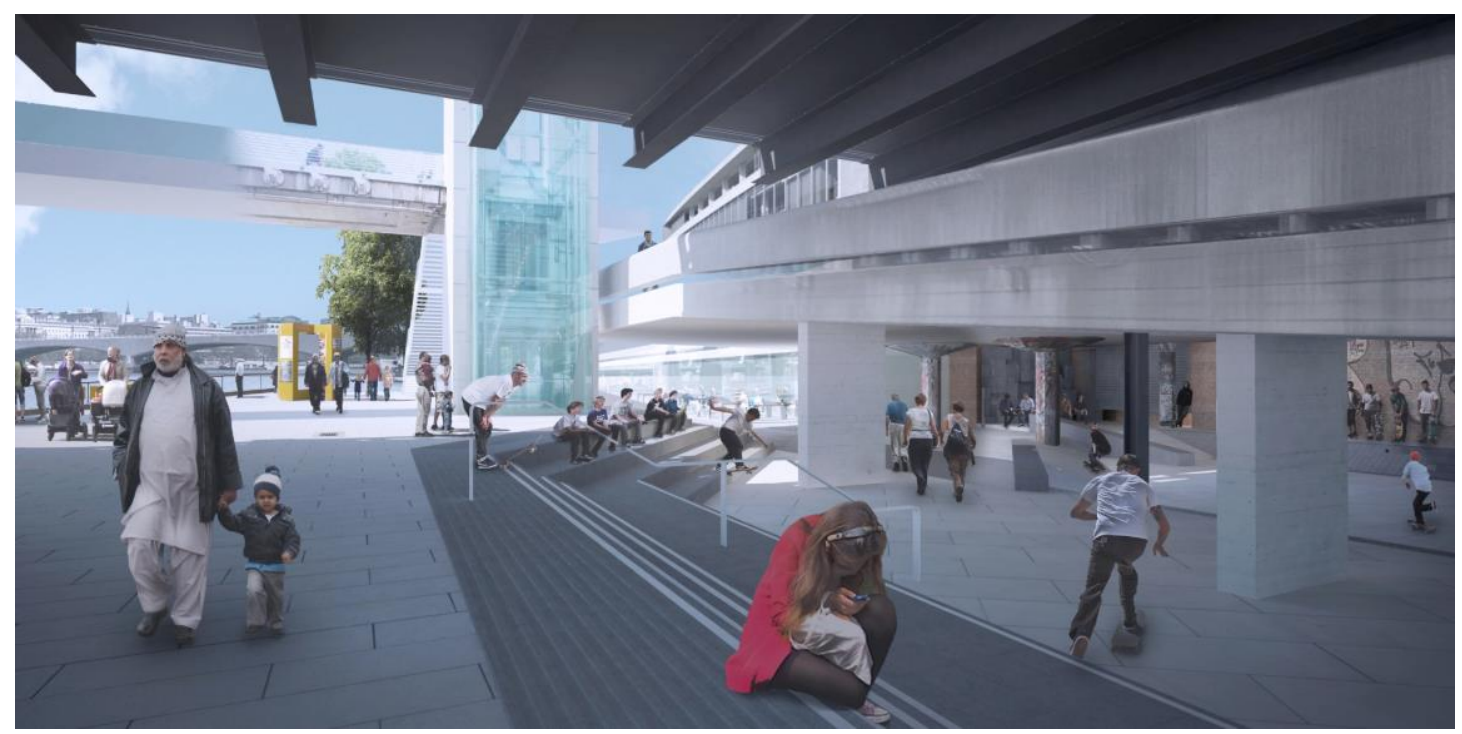

Should it ever be completed, this all bodes well for Hungerford Bridge. However, following the SBC's welcome decision to retain the Undercroft for skateboarding, and the subsequent impact upon SBC finances, the viability of Hungerford Bridge is currently uncertain. Although the SBC still apparently wishes to provide the Hungerford Bridge space - now as addition to rather than replacement for the Undercroft - this depends on funds being identified. Certainly, if and when created, this new skate space must fulfil the promise of Enevoldsen's collaborative design, providing the Undercroft's ledges, banks, rails and steps while avoiding the feel of an overtly-designed skatepark. It cannot have fees, fences or rules, but must be freelyopen, shared by all, a place skaters can appropriate and so help create a vibrant public skate space in the full sense of those terms.

\section{House of Vans}

Given skaters' vehement rejection of any suggestion that Hungerford Bridge become like a skatepark, it would be expected that any regulated and/or commercialised space in the vicinity would be equally fiercely opposed. Yet, at the "House of Vans", opened in 2014 just a few hundred metres from Hungerford Bridge, exactly this kind of space has appeared, and to considerable welcome.

The key element here is that the backers - clothing company Vans - has a carefully-nurtured and decades-long association with skateboarding. Originally founded in California in 1966 as a directselling shoe operation, by the end of the 1970s the affordable, grippy and durable nature of Vans shoes made them the de facto choice for skaters and surfers worldwide. (Palladini 2009) Subsequently during the 1980s, Vans realised that larger leisure markets could be targeted, and in 1988 it was sold to private equity investment firm McCown De Leeuw \& Co for US\$74.4 million. By 1996, Vans had already 
reached an annual turnover of US\$100, and by 2000 had shifted into extensive global non-skate markets, becoming a NASDAQ-traded company as a result. Sold again in 2004, this time to American conglomerate VF Corporation for around US\$400 million, by 2014 Vans global revenues had reached over US\$2 billion, with a goal of US\$2.9 billion by 2017. (Funding Universe 2015; TransWorld Skateboarding 1996; VFC 2013,2015 )

The enormous scale of these earnings could easily have generated accusations of Vans indulging in a commercial exploitation of skateboarding. Nike's skateboard-oriented sub-brand Nike SB, for example, and despite its occasional support for grass-roots initiatives like the Undercroft's skateable blocks, has sometimes been vilified as a non-skateboarding multinational's attempt to muscle-in on a skate scene worth around US\$5 billion in 2008. (Beal 2013). In particular, independent skate company Consolidated has vented anti-Nike and anti-corporate sentiments with its 'Don't Do It"' and "Don't Do It Foundation"' campaigns, warning against skateboarding being "hijacked by outsiders who have no passionate story in the surf, skate, and snowboard community''. (Bradstreet 2011; Hargrove 2012).

Given this denouncement of Nike - and Airwalk, Powell, Vision, World Industries and others have all faced similar criticism - it might be expected that Vans, with its global chain of shops selling leisure shoes and clothing predominantly to non-skaters, would encounter comparable condemnation. Unlike Nike, however, Vans have followed the advice of their 1990s public relations firm Weber Shandwick Worldwide (Browne 2004), carefully maintaining the appearance and behaviour of an organisation which, according to original family-owner steve Van Doren, 'has always been the underdog, the smaller company that scrapped and worked harder."' (Palladini 2009) This is sound advice in the field of action sports, where since the early 2000 s onwards marketing companies like Weber Shandwick and Fuse have constantly reminded corporate brands that they have to treat skateboarders as sensitively as when dealing with relgious groups. Skaters "want to see you support the sports not just on a mainstream level,"' warns Bill Carter of Fuse. "They don't want fanfare. They just want to see it. What they don't want to see is a brand coming with no grassroots support and just slapping a logo onto a high-profile event."' (Browne, 2004) For Vans, this has been achieved by supporting a slew of art, print, film and other creative initiatives - from $\$ 400,000$ towards the acclaimed Dogtown and the $Z-$ Boyz skate documentary (2001, dir. Stacy Peralta), to the recent "Vans Custom Culture"' project to inspire art and design in high schools - all demonstrating how Vans "gives back"' to the skate community. Hence also Vans' own directly skater-focused initiatives, ranging from skateparks, DIY constructions, Vans shop Riot and other 
competitions to the Offthewall.tv channel and "Living Off the Wall"' documentary series.

Particularly popular among skaters is the Vans Warped Tour, an eclectic mixture of action sports and rock, reggae, punk and hip-hop, and which every year attracts over 600,000 North American visitors. (Palladini 2009) In contrast to Nike SB'S headline sponsorship of the spectacularised and arena-based street League skateboarding international series, Vans have been more socially innovative in these operations. For example, since 2006 the Vans Warped Tour has incorporated the progressive All Girl Skate Jam competition inaugurated by Latina skater Patty Segovia-Krause, and which "sent shock waves through the male dominated skateboard industry."' (Beal 2013; I Skate Therefore I Am 2011) Indeed the whole Warped Tour is a "big backyard party"' where "freedom and chaos" co-exist; according to Tom Delonge of rock band Blink 182, the Warped Tour is a "cultural circus" and "the first cultural experiment of the post punker, alternative nation of kids.'' (Palladini 2009)

Vans have also been active in skateparks, most famously with a recreation of the Combi-Pool - the notoriously challenging squareand-round bowl installed at California's "Pipeline"' skatepark in 1979 and destroyed nine years later. Constructed within a skatepark in Orange County in 1999, Vans claim that its version of the CombiPool still "dares even the most experienced skater"' and, since 2005, has held an annual invitational "pool party" lasting several days, beamed live via the internet and YouTube highlights to hundreds of thousands of skaters worldwide.

\section{IMAGE 6 NEAR HERE}

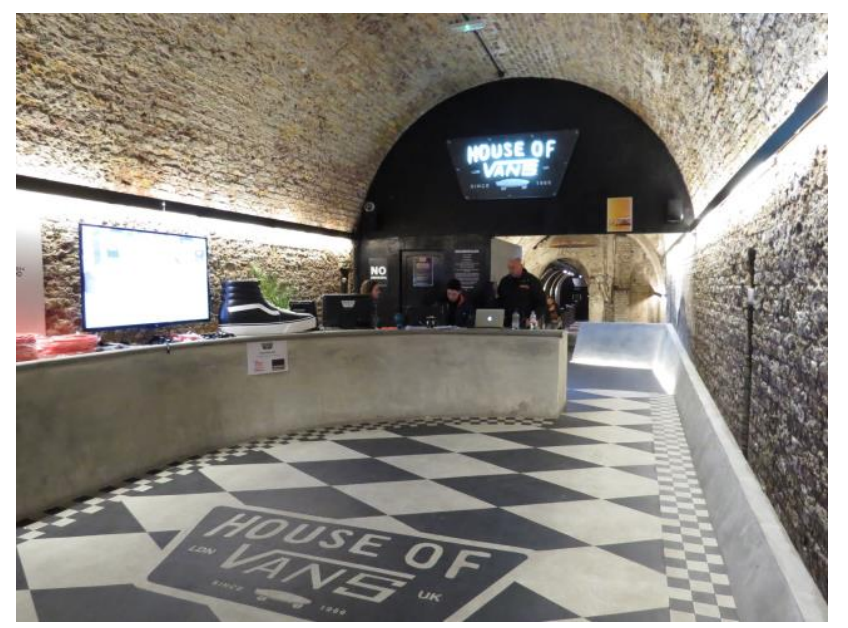

More inventive, though, is the "House of Vans"' initiative. First opened in 2010 with a club-like invite-only facility in Brooklyn, (NY Skateboarding 2011) and followed up by roving musicand skate-based events across America, the "House of Vans London" (HoV) version was opened in August 2014. Occupying 2,500m2 of 
Victorian railway arches (previously used by The Old Vic theatre for experimental arts), and located next to London's famous Leake street graffiti venue, HoV is a highly unusual combination of free-access skateboarding alongside art, music and film, thus furthering Vans' association creative producers.

As with Hungerford Bridge, this has been a collaborative production, deploying a team of marketeers, designers and fabricators with considerable prior experience working with Vans and/or the skate scene: Kat Mackenzie and Henry Clay of Black sparrow Presents (experiential marketeers) for event production and construction management, architect Tim Greatrex working with professional skateboarder and designer Pete Hellicar for overall design, professional skateboarder Marc Churchill of Line Skateparks for skatepark design, and Pete Warboys for skatepark construction. (Borden 2015; Greatrex 2015; House of Vans London 2014; Jones 2014)

Like the Hungerford Bridge open space designs for skaters and non-skaters, HoV adopts a multi-arts approach, where five tunnels are given discrete functions: art gallery, cinema, gig venue and skateboarding. Skate culture is symbolised through interior design features derived from concrete banks, swimming pools, drainage pipes and other skateboardable terrains, by a patterned rubber floor recalling the "waffle" sole of Vans shoes, and by vintage memorabilia. The skate spaces themselves cater for different abilities and interests, including a street area and mini-ramp. Most challenging is a complex-shaped bowl, "an unforgiving masterpiece that can destroy you and elate you,'" (Leeks 2014a) which combines varying transitions, heights, forms of coping and - in another reference to classic Vans shoes - black and white checkerboard tiling. Two iconic arch cut-outs - one per side wall - additionally demand from skaters a combination of exacting trajectory, advanced technicality and abundant bravado.

\section{IMAGE 7 NEAR HERE}

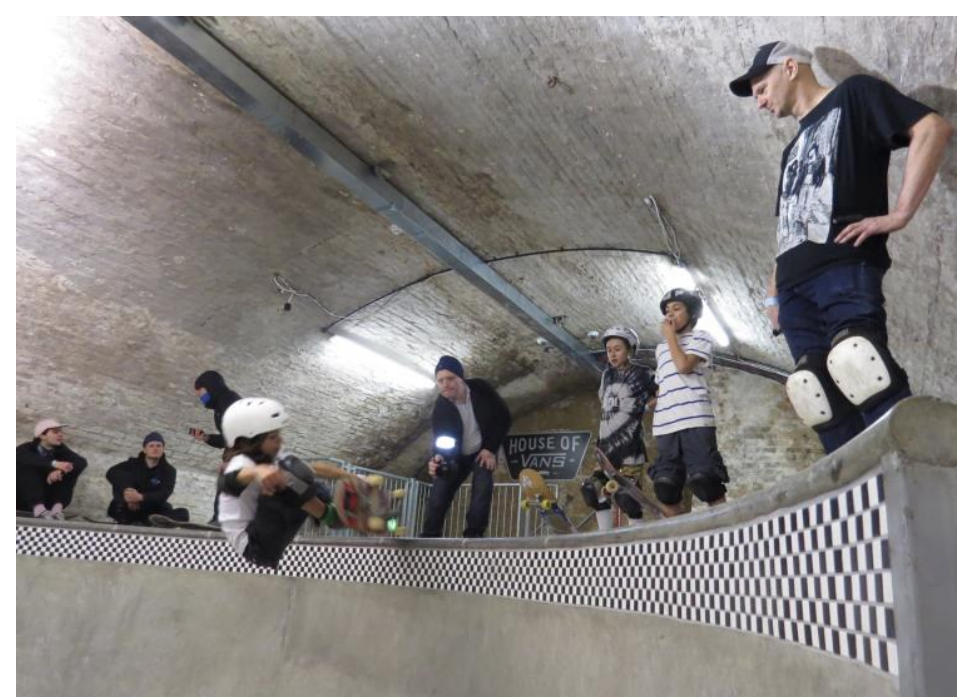


Unlike in Brooklyn, the London HoV is open to the public, including free skate, art and film sessions. The avowed intention of allowing Hov to evolve through its visitors seems, in the first few months at least, to be borne out by events ranging from movie screenings, drawing workshops and book fairs to exhibitions of skate art, graphics, photography and video. This kind of programming helps explain how, despite its global operations, Vans continues to enjoy, endorsements from creative producers like Lowbrow artist Niagara, graffiti artist Neck Face and skateboard graphic designer Wes Humpston, as well as musicians from Motorhead and Slayer to Public Enemy and Eminem. (Palladini 2009) HoV skatepark users are also surprisingly diverse, with one-third over 30 years old, and including significant numbers of similarly aged females - far more than skateparks typically attract. (Holden 2014) Social media, internet and live camera feeds have also helped connect HoV to local and international audiences. For example, the "Crossfire Halloween Massacre"' event - a "raucous night'" of jam skate sessions, deathpunks Turbonegro, "Massacre'" art and horror film screenings aired via a live web feed, and later appeared in innumerable on-line videos and blogs. (Leeks 2014b)

\section{IMAGE 8 NEAR HERE}

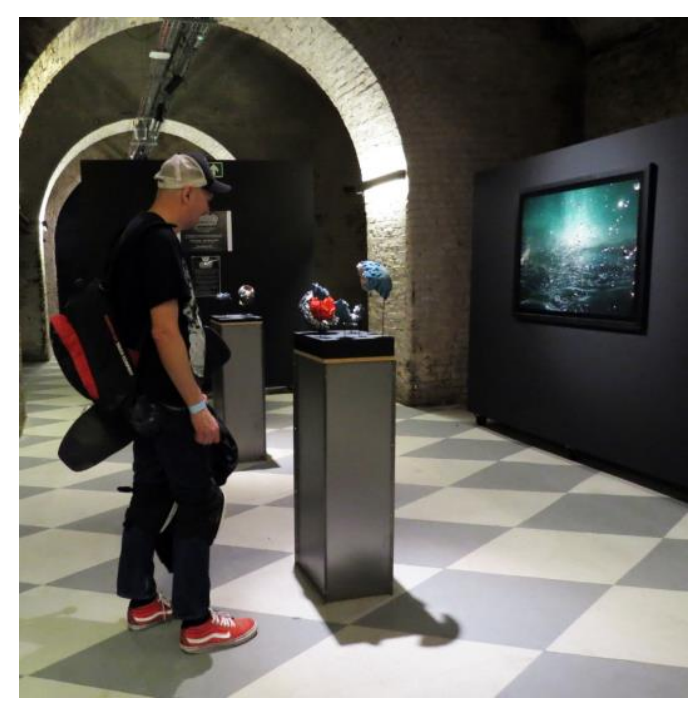

Despite operating as continuous advertisement for its billiondollar backer, HoV's wide artistic and social net is quite different to a typical skatepark, the carefully nuanced design and programme of activities encompassing at once some of the Undercroft's authentic urbanism, Hungerford Bridge's more varied skate terrains, and the creative artistic milieu commonly associated with skateboarding today, from film and photography to music, poetry and street art. In this context, HoV is clearly different to the corporate annexation of skateboarding and popular culture for which Nike SB and others have 
been criticised. It is also a step beyond the kind of corporate sponsorship (Mountain Dew, Pepsi etc.) which, as Tony Hawk has recently commented, allows skaters to get on with skateboarding yet remains outside of core skate values. (Hawk 2015) Hov, then, marks a shift in the outright opposition between, on the one hand, the authentic, real, street-level and unfunded (as many skaters commonly perceive skateboarding) and, on the other hand, the inauthentic, spectacularised, controlled and commercial (companies, sponsors, media); understood within the wider context of Vans and skateboarding, HoV is an example of what Lawrence Lessig has termed a "hybrid" economy, operating simultaneously as a commercial economy for financial gain and as a sharing economy for collaborative and collective benefit. (Lessig 2008) In short, HoV shows how the commercial, spectacular and controlled as well as the authentic, performative and disorderly might, in certain circumstances, exist in harmonious and even creative conjunction.

History will tell if this is too much to claim for Hov, which is very much in its infancy, and whose long-term future undoubtedly depends on Vans' financial success and, indeed, on HoV's own contribution to that prosperity; having cost UK£l million to fit out, plus an additional UK£l million per year to operate, the HoV facility clearly has to pay its way. There are also uncertainties about the other Southbank spaces. At the Undercroft, continued spats over usage (Wainwright 2015), the relative paucity of skateable terrain, and adjacent land-owners tightening up their anti-skate measures means that the LLSB campaign success just might, in years to come, appear more like a victory for nostalgia rather than for skateboarding's long term prosperity along the Southbank. At Hungerford Bridge, it is unclear how funding will be identified, and whether the SBC will ever construct it. Even then, questions remain as to how well Enevoldsen's design might be translated into built form, and, more importantly, how inspiring it might prove for skaters and others. Would it escape the stigma of being purposely provided for skaters, and could it become truly appropriated like a street skate spot?

But for now at least, there is much to be celebrated. Compared with the dark days of the 1980s when skateboarding all but disappeared in many nieghbourhoods, and even with the 1970 s when largely dismissed by public and media alike as a childish craze, skateboarding has now been accepted at the southbank as an established part of our urban, cultural and economic well-being. These three spaces show how skateboarding is vital to thousands of skaters, is appreciated by even greater numbers of the public, and is even essential to wider artistic and commercial operations. In these 
three spaces, skateboarding is at once indispensable, desirable and necessary. Here, for now, it thrives.

\section{References}

Armes, Andrew (2008). "SKM8,"' www.rudi.net/books/6911. [23 January 2015 ].

Beal, Becky (2013). Skateboarding: the Ultimate Guide, (Santa Barbara: Greenwood).

Bleasdale, Arron (1996). interview, Sidewalk Surfer, n.9 (August), unpaginated.

Blum, Andrew (2008). "New Oslo Opera House Is Really a stealth Skate Park,"' Wired, v.16 n.12 (24 November), www.archive.wired.com. [12 January 2015].

Borden, Iain (2001). Skateboarding, space and the City: Architecture and the Body, (Oxford: Berg).

Borden, Iain (2013). Long Live Southbank, "Iain Borden on the (Lack of) Festival Wing consultation,"' (18 September),

www. youtube.com/watch?v=EMQwktfjeTA\&spfreload=10. [19 September 2013]

Borden, Iain (2014a). 'Architecture,"' in Long Live Southbank, (2014) Long Live Southbank, (London: Long Live Southbank), pp. 68-97.

Borden, Iain (2014b). "The Spaces of Skateboarding,"' The Architects' Journal, (28 November), pp. 56-9.

Borden, Iain (2015). Interview with Tim Greatrex at the House of Vans London, (12 February).

Borden, Iain Borden and Holland, Richard (2013a). "Urban Arts at the Hungerford Bridge Site: Briefing for Designers,' (London: Southbank Centre, June/revised October).

Borden, Iain Borden and Holland, Richard (2013b). "Evaluation of the Hungerford Bridge Skate Space,"' report, Southbank Centre planning application \#13/05522/FUL, London Borough Lambeth, (26 November).

Bradstreet, Kailee (2011). "Thinking Small for the Future of Skate," TransWorld Business, available at www.consolidatedskateboard.com. [16 January 2015] . 
Brown, Mark (2014). 'Southbank skate Park Must Stay, Says Boris Johnson,"' The Guardian, (15 January), www.theguardian.com. [15 January 2014].

Browne, David (2004). Amped: How Big Air, Big Dollars, and a New Generation Took sports to the Extreme, (London: Bloomsbury).

Butter, Susannah (2014). "Wheels of Fortune," London Evening Standard, (14 April), www.standard.co.uk. [16 April 2014].

Clark, Katie and Hyland, Tim (2013). "Q\&A With Drexel Alum Tony Bracali,"' Drexel Now, (21 May 2013), www.drexel.edu. [6 June 2013]. Dezeen (2011). "Landhausplatz by LAAC Architeken and Stiefel Kramer Architecture,'" www.dezeen.com, (2 June). [27 November 2012].

Ethernal Skate Films (2013). "Big-O Rebirth @ The Pipe,"' www. youtube.com/watch?v=feRrG34LWY4 . [9 November 2013] .

Funding Universe (2015). "Vans. Inc. History,"' www.fundinguniverse.com. [26 January 2015]

Greatrex, Tim (2015). Tour of House of Vans with Iain Borden (19 February).

Hargrove, Kelli (2012). "The Don't Do It Foundation: Fighting to Save Speciality Retailers,"' www.business.transworld.net (31 July). [16 January 2015].

Harvey, David (2003). "The Right to the City," International Journal of Urban and Regional Research, v.27 n.4, pp. 939-41. Hawk, Tony (2015). 'Tony Hawk: Who You Callin' a Sell out?,' The Berrics, (23 January), www.theberrics.com. [26 January 2015].

Holden, Lucy (2014). 'Skate Ramps Buzz with Old City Rollers,"' The Times, (23 August), www.thetimes.co.uk. [24 August 2014].

Holland, Richard (2015). Email to Iain Borden (30 January).

House of Vans London (2014). Press release, (July).

Howell, Ocean (2005). 'The 'Creative Class' and the Gentrifying City: Skateboarding in Philadelphia's Love Park,'' Journal of Architectural Education, v.59 n.2, pp. 32-42. 
I skate Therefore I Am (2011). "Interview with Patty Segovia, creator of All Girl Skate Jam"', www.istia.com, (2 November). [22 March 2012].

Jones, Guy (2014). 'House of Vans London Sneak Peak,"' Sidewalk, (14 July), www.sidewalk.mpora.com. [1 September 2014] .

Leeks, Zac (2014a). 'Vans X Crossfire Halloween Massacre Bowl Jam Gallery," Crossfire, (3 November), www.caughtinthecrossfire.com. [4 November 2014].

Leeks, Zac (2014b). 'Vans X Crossfire Halloween Massacre 2014,"' Crossfire, (7 october), www.caughtinthecrossfire.com. [15 November 2014 ].

Lefebvre, Henri (1991). The Production of Space, (Oxford: Blackwell). Lessig, Lawrence (2008). Remix: Making Art and Commerce Thrive in the Hybrid Economy, (New York: Penguin Press).

Long Live Southbank (LLSB) (2013a). "A Bigger Picture"' (November), www. youtube.com/watch?v=iFaKN98Xg3E\&spfreload=10. [15 November 2013].

Long Live Southbank (LLSB) (2013b). "Response to the Southbank Centre's Hungerford Bridge skatepark plans,' (10 September), www. youtube.com/watch?v=908Iudxi90o. [11 september 2013].

Long Live Southbank (LLSB) (2014a). "Southbank Undercroft: Cultural \& Heritage Assessment Report,'" (London: Long Live Southbank, September).

Long Live Southbank (LLSB) (2014b). Long Live Southbank, (London: Long Live Southbank, 2014).

New York Skateboarding (2011). "The House of Vans - Brooklyn,', www.nyskateboarding.com. [16 January 2015] .

Owens, Cassie (2014). ''Skateboard Urbanism' Could Change Park Planning," Next City, (1 October), www.nextcity.org. [21 January 2015 ].

Palladini, Doug (2009). Vans: Off the Wall. Stories of Sole from Van's Originals, (New York: Harry N. Abrams).

Philly Love Notes (2013). "The One Place Michael Haeflinger Loves?"' (22 october), www.phillylovenotes.com. [1 December 201]). 


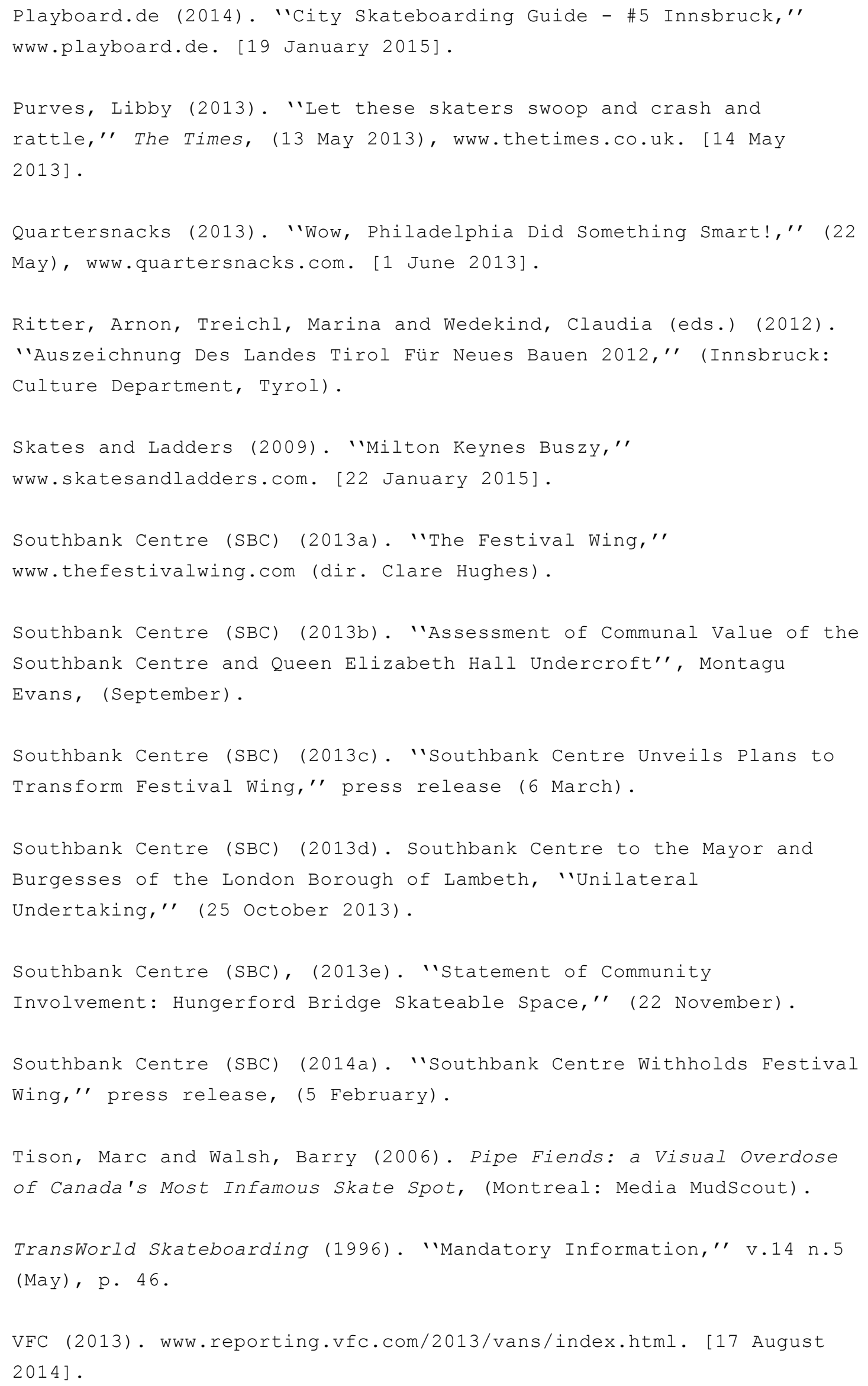


VFC (2015). Press release, 'VF Reports 2014 Fourth Quarter and Full Year Results; Announces Outlook for 2015,'" www.vfc.com. [17 February 2015].

Wainwright, Oliver (2015). "Southbank Bans Street Art Event Celebrating Skate Park's Salvation,'" The Guardian, (28 January 2015), www.theguardian.com. [28 January 2015].

Wheatcroft, Geoffrey (1979). "Busk Off,"' The Spectator, (24

February), p. 28 .

Whitter, Winstan and Shuall, Toby (2008). "Save South Bank,' www.vimeo.com/32716340. [12 November 2012].

$<\operatorname{ENDS}>>$

\section{Iain Borden}

Iain Borden is Professor of Architecture \& Urban Culture, and ViceDean Communications, at The Bartlett, University College London. Iain's authored and co-edited books include Forty Ways to Think About Architecture (Wiley, 2014), Drive: Journeys through Film, Cities and Landscapes (Reaktion, 2012), Bartlett Designs: Speculating With Architecture (Wiley, 2009), Manual: the Architecture and office of Allford Hall Monaghan Morris (Birkhauser, 2003), Skateboarding Space and the City: Architecture and the Body (Berg, 2001/new edition forthcoming), The Unknown City: Contesting Architecture and Social Space (MIT, 2001) and InterSections: Architectural Histories and Critical Theories (Routledge, 2000).

\section{Image captions}

1 Ben Jobe, backside tailside at the Undercroft's seven-stair in 1996. (c) Wig Worland.

2 Richard Holland (second from right) and others installing skateable blocks at the Undercroft in 2006. (c) Wig Worland.

3 Final design for the Hungerford Bridge skate space, 2013. () Søren Nordal Enevoldsen/SNE Architects.

4 Plan of Hungerford Bridge skate space, 2013. () Søren Nordal Enevoldsen/SNE Architects. 
5 Final design for the Hungerford Bridge skate space, 2013. ( Søren Nordal Enevoldsen/SNE Architects.

6 Reception area, House of Vans, 2015. (C) Iain Borden.

7 Skateboarding bowl, House of Vans, 2015. () Iain Borden.

8 "Celestial Anomalies"' exhibition of the work of Jethro Haynes, House of Vans, 2015. (c) Iain Borden. 